\title{
THE STATUS OF MOLLUSK DIVERSITY AND PHYSICAL SETTING OF THE MANGROVE ZONES IN CATANDUANES ISLAND, LUZON, PHILIPPINES
}

\author{
JIMMY T. MASAGCA ${ }^{1,2}$ ANGELICA V. MENDOZA ${ }^{2}$ and \\ ESTRELLA T. TRIBIANA ${ }^{2}$ \\ ${ }^{1}$ Pacific Island Institute for Pedagogy, Technology, Arts \& Sciences, Inc. \\ De La Salle University-Dasmariñas, Philippines \\ ${ }^{2}$ Catanduanes State Colleges, Calatagan, Virac 4800, Catanduanes, Philippines
}

Received 06 August 2010 / Accepted 13 September 2010

\begin{abstract}
The status of mollusk diversity and physical setting of mangrove areas in Catanduanes island, Luzon (Philippines) are described. A total of 57 species of mollusks, consisting of 27 gastropods and 30 bivalves were recorded in the island. Registering higher values of species diversity indices (Margalef) and species richness (Menhinick) are the prosobranch, Terebralia sulcata; corbiculid bivalve, Geloina coaxans; potamidiids, Cerithidea cingulata and Cerithidea rhizophorarum; and two other species of the genus Littorina (Littorinopsis). Using the physiographic model, majority of the mangrove areas under study follow the composite river and wave-dominated setting with some few areas having the wave-dominated, tide-dominated allochthonous setting.
\end{abstract}

Keywords: Mollusk diversity, mangrove areas, Philippines

\section{INTRODUCTION}

In recent years, there had been an increased interest on the status of mangrove areas in tropical coastal ecosystems for economic and ecologic reasons (McNeely et al. 1990, Maler 1997, Masagca 2006). These are the most biologically diverse of all marine ecosystems but are being degraded worldwide by human activities potentially leading to numerous extinctions (Rios-Jara 2009). Conservation efforts targeted toward these ecosystems could help in averting the loss of tropical biodiversity. The first step according to Hamilton and Snedaker (1984) towards the attainment of the goals of conservation and sustainable use of the mangrove ecosystem is to develop data base. This is a comprehensive collection of information on such subjects as the areas and distribution of mangroves their flora and fauna present.

*Corresponding author: jmasagca@yahoo.com 
In the tropical coastal environments, the mollusks are among the most diverse invertebrates and the vast majority is found intertidally, in estuaries, coastal lagoons, and in the shallow areas of the continental shelf (Brusca \& Brusca 1990, Hendrikx et al. 2007). Mollusks have colonized all possible habitats (from deep sea to high mountains) and are found to be abundant in tropical littoral zones (Shanmugam \& Vairamani 2009). In the mangrove swamps, the mollusks and crustaceans are the most conspicuous faunal elements (Macnae 1968, Morton 1990).

Recognizing the importance to conserve the remaining mangroves and their associated faunal elements, such as the mollusks of Catanduanes (Philippines), as well as the paucity of studies on malacological diversity, this inquiry was carried out. The mollusk fauna of this island has received little attention. Studies were carried out mostly by faculty members and their students at the Catanduanes Colleges in Virac, Catanduanes but are unpublished. Earlier inventories of mollusks from the areas under consideration were performed by the present authors in the 1980s and continued until 2009. Most of these researches are included in the book of abstracts in conferences and in not easily accessible technical reports and undergraduate theses. Studies also refer to specific municipalities and environments of the coastal areas. More complete lists of species from this island are now being prepared in order to have a comprehensive cataloguing and reporting in journals and other conference proceedings.

The structure of mangrove ecosystem is related to the abiotic components. The abiotic components are composed of the physical and chemical environment such as solar radiation, temperature, rainfall, nutrients and water supply (Aksornkoae 1993). On the environmental setting or physical setting, Thom (1984) stressed that a basic task confronting the mangrove ecologist is to explain the development of mangrove communities through time. In an attempt to explain the mangrove associated fauna in the island under study, the species diversity of mollusks and physical setting of the mangrove areas are described here with the hope in finding possible explanations to the local area distribution in future publications.

The paper deals with the species of bivalves and gastropods found in the most representative environments of the mangrove areas and includes a checklist of species and species richness along 10 different municipalities (within the 6 ecological zones of the island) with mangrove stands found in estuaries, riverine and marine dominated mangrove areas associated with the shallow subtidal of the continental shelf. This list is an attempt to both provide a more complete inventory of the mollusks fauna of this island and update the taxonomic names. In addition, the materials collected were deposited in the currently organized biodiversity reference collections project of the Pacifictech in Catanduanes and the Natural Sciences Department Reference Collections at the Catanduanes State Colleges, Philippines.

\section{MATERIALS AND METHODS}

\section{Location of the study}

Catanduanes is an island province (total land area of $1,483 \mathrm{sq} \mathrm{km}$ ) of the eastern part of the Philippine archipelago $\left(13.5^{\circ}\right.$ to $14.1^{\circ} \mathrm{N}$ Lat. and $124^{\circ}$ to $125^{\circ} \mathrm{E}$ Long.). 
Highest elevation of the island is $803 \mathrm{~m}$ above sea level. The monsoonal climate of the province consists of two distinct dry season and wet season. Typical diurnal range of temperatures is $25^{\circ}$ to $32^{\circ} \mathrm{C}$ with minimal variations throughout the year. Relative humidity varies from 75 to $89 \%$. Most likely, the current that affects the island is the North Equatorial Current moving westward across the Pacific.

\section{Research methods, sources of data and sampling procedures}

Heywood (1995) propounded that characterizing biodiversity involves the observation and characterization of the main units of variation (e.g. Genus and species) as well as the quantification of variation within and between them (e.g. taxonomic relatedness). Ocular and transect surveys were employed in gathering data on the mangrove associated components of the mangroves in the island. Primary data were from direct systematic surveys or observation of the mangrove areas in the island. Laboratory observations were done to identify the mollusks not identified in situ.

The study sites cover the whole island, except for a landlocked municipality and a coastal town without a distinct mangrove area suited for scientific observation. There were 6 study zones established in the province for the purpose of showing the whole province as an ecological unit for analysis.

\section{Data gathering procedures}

The procedures developed by Sasekumar (1984) and that of Dartnall and Jones (1986) were followed in this inquiry. Before field surveys were carried out in the zones (Table 1), specific objectives were determined and information sought were clearly explained to the research assistants. Using the topographic maps imaginary transect lines were assigned for every ecological zone. Using Google Earth, topographic maps were enhanced and traced for overlaying and comparison of existing maps obtained from NAMRIA. One of the most difficult decisions made when obtaining data for the mollusks was how many replicate samples were to be required at each study station or substation to get the reliable information. Many taxa of mollusks are not distributed uniformly over the bottom of the mangrove ecosystem. Different habitats (i.e. sand, mud, gravel or organic material) will support different densities and species of organisms. During field surveys, even on a relatively homogeneous bottom, it was observed that mollusks tend to aggregate. With this, replicate samples (or 10 quadrats) were used to evaluate this variability.

Table 1. Arbitrary ecological zones on Catanduanes Island, Luzon

\begin{tabular}{cll}
\hline Zone & Zonal Location & Municipality \\
\hline I & Northern & Pandan (PAN-06) \\
II & Northwestern & Caramoran (CAR-04) \\
III & Northeastern & Panganiban (PAG-07), \\
& & Viga (VIG-09), Bagamanoc (BAG-01) \\
IV & Southern & Virac (VRC-10) \\
V & Southeastern & Bato (BAT-03), Baras (BAR-02), \\
& & Gigmoto (GIG-05) \\
VI & Southwestern & San Andres (SAN-08) \\
\hline
\end{tabular}


From the reference point, 20 to 21 quadrats measuring $1 \mathrm{~m} \times 1 \mathrm{~m}$ were determined in each transect line. To permit comparison of mollusks communities, it was ensured that all the quadrats in the transect line were ecologically similar. During the survey, obstructions like boulders of large logs lying on transects were encountered. To compensate for this invalid quadrat, the wooden sheet frame was thrown at any direction to sample the mollusks. Collection and identification of mollusks were carried out following several keys with the assistance of Mr. Jaime Cabrera, Conchologist of the Philippine National Museum (PNM).

Mollusk biodiversity measurements were made using Margalef's Index of Community Diversity (Magurran 1988) and Menhinick's Index for Species Richness (Shanmugam \& Vairamani 2009). As measure of species diversity, Margalef's index is calculated from the total number of species present and the abundance or total number of individuals, wherein the higher the index the greater the diversity. The species richness index of Menhinick attempts to compensate for sample effects by dividing richness, $S$, the number of species recorded, by $N$, the total number of individuals in the sample (Magurran 1988).

\section{Physical setting}

In an attempt to explain the mangrove associated mollusk in Catanduanes, three models were used for convenience in describing the physical setting of mangrove ecosystems, namely: 1.) Succession Model 2.) Gradient Analysis Model, and 3.) Physiographic Model. However, considering the applicability of the third model, discussion based on this model was focused in this paper. Maps from NAMRIA as well as data obtained from Google Earth were used in this report.

\section{RESULTS AND DISCUSSIONS}

\section{Mollusks associated with mangrove areas of Catanduanes island, Philippines}

The bivalves and gastropods were registered in the mangrove areas found in ten (10) coastal municipalities of the island province. For the first time, a total of 57 taxa of mollusks, composed of 27 species of gastropods and 30 species of bivalves that were identified in the mangrove areas under consideration. The bivalves belong to 4 orders, 13 families, and 23 genera, and the gastropods belong to 3 orders, 12 families, and 14 genera (Table 2).

Early inventory of the bivalves and gastropods in brackishwater areas (including the mangrove areas) of Catanduanes is attributed to the work of Mendoza and Tribiana (1997) which comprises 15 species of gastropods (belonging to 10 genera, 10 families and 3 orders); and 22 species of pelecypods (belonging to 17 genera, 11 families and 3 orders). Their work provides baseline information on species list, but not on new species, redefinitions of taxonomic relationships, new records, and their geographic distributions which will be the focus of future serial reports on the malacalogical fauna of the island. However, most of the literature on the mollusks from this part of the Philippines refers to coastal benthic communities of the Maqueda Channel in Lagonoy Gulf and the eastern coasts of the island facing the Philippine Sea. 
Table 2. Total number of orders, families and genera of bivalves and gastropods identified in the mangrove areas of Catanduanes.

\begin{tabular}{llllll}
\hline Mollusks & Order & Family & Genera & Species & $\%$ \\
\hline Bivalves & 4 & 13 & 23 & 30 & 47.9 \\
Gastropods & 3 & 12 & 14 & 27 & 52.1 \\
Total & 7 & 25 & 36 & 57 & 100 \\
\hline
\end{tabular}

Combining the reports on mollusks contained in the papers of Mendoza \& Tribiana (1997), Masagca (2000), Masagca and Masagca (2009) and other unpublished undergraduate theses at the Catanduanes State Colleges, Philippines, an updated taxonomic list of the mollusks found in the mangrove areas of Catanduanes is presented below.

CLASS GASTROPODA Cuvier, 1797

Subclass Prosobranchia A. Milne-Edwards, 1848

Order Archaeogastropoda Thiele, 1925

Superfamily Trochacea Rafinesque, 1815

Family Trochidae Rafinesque, 1815

Genus Monodonta Lamarck, 1799

1. Monodonta labio Linnaeus, 1758

2. Trochus niloticus Linnaeus, 1758

3. Trochuspyramis Born, 1778

4. Trochus maculatus

Superfamily Neritaceae Rafinesque, 1815

Family Neritidae Rafinesque, 1815

Genus Nerita Linnaeus, 1758

5. Nerita chamaeleon Linnaeus, 1758

6. Neritaplanuspira Anton, 1839

7. Nerita (Theliostyla) squamulata

8. Nerita undulata Linnaeus 1780

Order Mesogastropoda Thiele, 1925

Superfamily Littorinacea

Family Littorinidae Gray, 1840

Genus Littorina Ferussac, 1822

9. Littorina (Littorinopsis) scabra Linnaeus, 1758

10. Littorina littoralis Linnaeus. 758

11. Littorina (Littorinopsis) planospira

Superfamily Cerithiacea Fleming, 1822

Family Cerithiidae

Genus Cerithium Bruguiera, 1789

12. Cerithium patulum Sowerby, 1834

13. Cerithium pfefferi Dunker, 1822

14. Cerithium vertagus Linnaeus

Family Potamididae

Genus Cerithidea Swainson, 1840

15. Cerithidea rhizophorarum A. Adams, 1855 
16. Cerithidea cingulata Gmelin, 1822

Genus Telescopium Linnaeus, 1758

17. Telescopium telescopium Linnaeus, 1758

Genus Terebralia Swainson, 1840

18. Terebralia sulcata Born, 1778

Family Strombidae

Genus Strombus Linnaeus, 1758

19. Strombos gracilior Sowerby, 1825

Family Cypraecidae

Genus Cypraea

20. Cypraea clandestine Linnaeus, 1767

21. Cypraea erosa Linnaeus, 1758

22. Cypraea moneta Linnaeus, 1758

Order Neogastropoda

Family Buccinidae

Genus Cantharus Roding, 1798

23. Cantharus undosus Linnaeus, 1758

Family Melonggeniidae

Genus Melonggena Schumacher, 1857

24. Melonggena galeodes Lamarck

Family Muricidae

Genus Pteronotus Swainson, 1833

25. Pteronotus elongate

Superfamily Buccinacea

Family Nassaridae

Genus Nassarius Dumeril, 1806

26. Nassarius olivaceous Bruguiera, 1789

Superfamily Muricacea

Family Thaididae

Genus Morula Schumacher, 1817

27. Morula fiscella Gmelin, 1791

CLASS BIVALVIA LINNAEUS, 1758

Subclass Pteriomorphia Beurlen, 1944

Order Arcoida Stoliczca, 1817

Superfamily Arcacea Lamarck, 1809

Family Archidae Lamarck, 1809

Genus Anadara Gray, 1847

28. Anadara antiquate Linnaeus, 1758

29. Tegilaria granosa Linnaeus, 1758

Genus Barbatia Gray, 1842

30. Barbatiasp.

Order Pteroida Newell, 1965

Superfamily Pteriacea Gray, 1847

Family Pteriidae 
Genus Pteria

31. Pteria maxima

Family Isognomidae

Genus Isognomon Lightfoot, 1786

32. Isognomon ephippium Linnaeus, 1758

33. Isognomon isognomon

Family Placunidae Yonge, 1977

Genus Placuna Lightfoot 1788

34. Placuna placenta Linnaeus, 1758

35. Placuna sella Gmelin 1791

Subfamily Ostreacea Rafinesque, 1815

Family Ostreidae Rafinesque, 1815

Genus Crassostrea Sacco, 1897

36. Crassostrea echinata Quoy \& Gaimard, 1836

37. Crassostrea lugubrious Sowerby

38. Crassostrea tuberculata Lamarck, 1819

Order Mytiloida Ferussac, 1822

Superfamily Mytilacea Rafinesque, 1815

Family Mytilidae Rafinesque, 1815

Genus Septifer Recluz, 1848

Family Dreissenidae

39. Septifer bilocularis Linnaeus, 1758

Genus Dreissena van Beneden, 1838

40. Dreissena sp.

Family Cardiidae Lamarck 1809

Genus Regozara

41. Regozara flava Linnaeus, 1758

Genus Trachycardium

42. Trachycardium pristipleura (Dall, 1901)

Family Corbiculidae Gray 1847

Genus Geloina Gray 1842

43. Geloina coaxans Gmelin, 1791

Subclass Heterodonta Neumayr, 1884

Order Veneroida H \& A. Adams, 1856

Superfamily Veneracea Rafinesque, 1815

Family Veneridae Rafinesque, 1815

Genus Circe Schumacher, 1817

44. Circe (Lioconcha) castrensis Linnaeus, 1758

45. Circe scripta Linnaeus, 1758

Genus Grafarium Roeding, 1789

46. Grafarium tumidum Roeding, 1789

47. Grafarium pectinatum Linnaeus, 1758

Genus Marcia H. \& A. Adams, 1857

48. Marcia sp. H. \& A. Adams, 1857

Genus Dosinia Scopoli, 1777 


\section{Dosina sp. (Reeve) \\ Genus Pitar Romer 1857}

50. Pitarfrizelli J. G. Hertlein \& A. M. Strong, 1948

Genus Tivela Link 1807

51. Tivela delesertii (Sowerby, 1854)

Genus Venus Linnaeus 1758

52. Venus (Paphia) englypta Philippi 1847

53. Venus merunaria Linnaeus, 1857

Family Mactridae Lamark 1809

Genus Mactra Linnaeus 1767

54. Mactrasp.

Family Donacidae Fleming 1858

Genus Donax Linnaeus 1758

55. Donax mirabilis Linnaeus, 1857

Family Lucinidae Fleming 1828

Genus Lucinoma Dall 1901

56. Lucinoma annulatum Reeve, 1850

Genus Anodontia Link 1807

57. Anodontia alba Link, 1807

Most of the species (57) were collected in the mangrove areas found in the municipalities of Bato, San Andres and Panganiban. The number of species per family varies considerably (1 to 10 species). Six families of bivalves (46.2\%) and 6 families of gastropods $(50 \%)$ are represented by one single species; the most diverse families of bivalves are: Veneridae (10 species), Archidae (3), Ostreidae (3), and the most diverse families of gastropods are: Potamididae (4), Neritidae (4), and Trochidae (4).

The bivalves found in the northeastern portion (Zone III) mangrove areas in Viga and Panganiban are typically associated to soft substrata. These areas are rich with alluvial deposits. A few epifaunal bivalves live adhered to the mangrove roots. This group includes the mytiliid Septifer bilocularis, the oysters Crassostrea echinata, C. lugubrious, Isognomon ephippium and I. isognomon. The windowpane shells, Placuna placenta and $P$. sella are found in the soft muddy substrates of the mangrove areas in the island.

Gastropods found in the mangrove areas of San Andres, Baras and Bato are mostly associated to the marine environment. Three species of the family Cypraecidae and 4 species of the family Trochidae were obtained from the mangrove areas which are usually associated to estuarine habitats and sandy substrata. The collections of the species belonging to the family Trochidae, with 4 species (Monodonta labio Linnaeus, 1758, Trochus niloticus Linnaeus, 1758, T. pyramis Born, 1778 and T. maculates are obtained from the sandy-muddy substrates of the mangrove areas in the southeastern portion (Zone V) composed of Bato and Baras and in the southwestern portion (Zone VI) composed of San Andres. In general, the said mangroves in these municipalities consisting of Tide Dominated Allochthonous and Wave-Dominated settings have greater number of mollusk species. There is a great possibility that the substrates are derived from carbonate materials.

The mangrove areas in Bato and to some extent, San Andres have shallow water 
bodies that contain a distinctive group of species, some living on the roots of the mangrove Rizophora apiculata and $R$. mucronata. Species that are exclusive to the mangrove habitat were recorded; among these, the members of family Neritidae (Nerita chamaeleon, N. (Thylostyla) squamulata), family Littorinidae (Littorina scabra, L. littoralis and L. planospira), and the prosobranchs of the family Potamididae (Terebralia sulcata, Telescopium telescopium, Cerithidea cingulata, C. rhizophorarum, Cerithium pathulum, C. pfefferiand C. Vertagus).

The long spired prosobranch, T. sulcata Born, 1778 occurs in the mangrove areas in large numbers particularly in most types of muddy substrates. This prosobranch has close association with Cerithidea rhizophorarum in the mudflats. T. sulcata is proposed as a biological indicator in pollution studies because of its fast growth and distributional range (Masagca 2000). The presence of the gastropods, Cypraea moneta and Littorina sp. in the mangrove sites of San Andres, Bato and Baras indicates the greater marine influence on the macrofauna of these areas.

\section{Species diversity and richness of mollusks in the mangroves of Catanduanes}

Table 3 presents the various reports on the mollusks associated with mangroves in the Philippines and other countries.

Table 3. Summary of mollusks associated with mangroves in different locations.

\begin{tabular}{|c|c|c|c|c|}
\hline Locations & Author/s & Gastropods & Bivalves & $\begin{array}{l}\text { Total No. of } \\
\text { Mollusks } \\
\text { species }\end{array}$ \\
\hline Philippines & Zamora (1989) & 49 & 15 & 64 \\
\hline Australia & Tomlinson (1986) & $\mathrm{Nd}$ & nd & 95 \\
\hline Indonesia & $\begin{array}{l}\text { Soemodihardjo and } \\
\text { Sorianegara (1989) }\end{array}$ & 51 & 37 & 88 \\
\hline Catanduanes & This report & 27 & 30 & 57 \\
\hline
\end{tabular}

Zamora (1989) reported 49 species of gastropods and 15 species of bivalves associated with mangroves in the Philippines. There seems to be a higher number of bivalve species reported earlier by Mendoza and Tribiana (1997) and this report compared to that of Zamora (1989). The former may have included truly marine species of pelecypods, which are said to be abundant in the Agoho mangrove area characterized by Tide Dominated Allochthonous Setting favoring the presence of additional species of mollusks. The zonal distribution and systematic study of Reyes (1979) in Puerto Galera, Mindoro identified 15 species of gastropods and 10 species of bivalves.

In Australian mangroves, Tomlinson (1986) noted 95 species of mollusks, and in other southeast Asian countries, Indonesia has 51 species of gastropods represented by families Potamidae, Ellobidae, Nassaridae, Thiaridae, Littorinidae, Neritidae and Muricidae. Mangrove bivalves in Indonesia are represented by Corbiculidae, Veneridae, Cerithidae, Melongenidae, Ostreidae, Mytilidae, Spondylidae and Arcidae (Soemodihardjo \& Soerianegara 1989). 
Estimation of the parameters for diversity of mollusk fauna was initially carried out in the island using 21 quadrats in each of the 8 study locations. Data in the number of mollusks obtained during sampling for this study was recorded. Summary of the computation as to Species Diversity uses Margalef's species diversity index. It can be gleaned from Table 4 that Terebralia sulcata had the highest diversity index at 0.59, followed by Cerithidea rhizophorarum (0.44), Geloina coaxans (0.42), Anadara antiquate (0.36), Nerita (Thelostyla) squamulata (0.25) and N. chamaeleon (0.24). Molluscan species with diversity indices below 0.1 are Morula fracella (0.098), Monodonta labio, Dossinia sp. (0.088), Crassotrea tuberosum (0.071), Barbatia (0.081) and Cypreae moneta ( 0.083 ). In Margalef's index of community diversity, the higher value the higher the diversity. De la Cruz and Banaag (1967) reported the abundance of gastropods belonging to the genera Cerithidea, Littorina and Moneta. These genera are also abundant in the mangrove areas of Catanduanes. In Venezuelan mangroves, the genera Neritina, Littorina and Thais are reported to be abundant in roots and trunks of the mangrove trees.

Table 4. Species Diversity (Margalef's Index) of mollusks found in the mangrove areas of Catanduanes island, Luzon, Philippines.

\begin{tabular}{|c|c|c|c|c|c|c|c|c|c|c|}
\hline \multirow{2}{*}{$\begin{array}{l}\text { Species of } \\
\text { Mollusk }\end{array}$} & \multicolumn{9}{|c|}{$\begin{array}{c}\text { Species Diversity (Margalef's index) of Mollusks in the Different } \\
\text { Mangrove Areas }\end{array}$} & \multirow[t]{2}{*}{ Rank } \\
\hline & $\mathrm{I}$ & II & III & IV & $\mathrm{V}$ & VI & VII & VIII & Mean & \\
\hline $\begin{array}{l}\text { Anadara } \\
\text { antiquata }\end{array}$ & 0.35 & 0.3 & 0.33 & 0.23 & 0.24 & 0.45 & 0.90 & 0.09 & 0.361 & 4 \\
\hline Barbatia & 0.15 & 0.05 & 0.05 & 0.05 & 0.10 & 0.10 & 0.10 & 0.05 & 0.081 & 24 \\
\hline $\begin{array}{l}\text { Cerithidea } \\
\text { cingulata }\end{array}$ & 0.10 & 0.1 & 0.14 & 0.05 & 0.05 & 0.10 & 0.50 & 0.41 & 0.180 & 10 \\
\hline $\begin{array}{l}\text { Cerithidea } \\
\text { rhizophorarum }\end{array}$ & 0.80 & 0.6 & 0.62 & 0.05 & 0.05 & 0.05 & 0.60 & 0.73 & 0.438 & 2 \\
\hline Cerithium pfefferi & 0.20 & - & 0.05 & 0.09 & 0.10 & 0.05 & 0.15 & - & 0.106 & 20 \\
\hline Cerithium patulum & 0.15 & - & - & - & - & 0.05 & 0.25 & 0.05 & 0.125 & 18 \\
\hline $\begin{array}{l}\text { Crassostrea } \\
\text { echidna }\end{array}$ & 0.35 & 0.05 & 0.05 & 0.09 & - & 0.15 & 0.1 & - & 0.131 & 14.5 \\
\hline $\begin{array}{l}\text { Crassostrea } \\
\text { tuberosum }\end{array}$ & - & - & 0.09 & 0.09 & 0.05 & - & 0.05 & - & 0.070 & 26 \\
\hline Cyprea moneta & 0.05 & 0.10 & - & - & 0.10 & - & - & - & 0.083 & 23 \\
\hline Dossinia sp. & 0.10 & 0.01 & - & 0.14 & - & 0.10 & - & - & 0.088 & 22 \\
\hline Geloina coaxans & 0.60 & 0.2 & 0.48 & 0.55 & 0.48 & 0.05 & 0.6 & 0.41 & 0.421 & 3 \\
\hline $\begin{array}{l}\text { Grafrarium } \\
\text { tumidum }\end{array}$ & 0.35 & 0.05 & 0.19 & 0.14 & - & 0.10 & 0.2 & - & 0.172 & 12 \\
\hline $\begin{array}{l}\text { Isognomon } \\
\text { ephipium }\end{array}$ & 0.15 & 0.1 & 0.14 & 0.18 & 0.10 & 0.15 & 0.1 & - & 0.131 & 14.5 \\
\hline $\begin{array}{l}\text { Littorina } \\
\text { (Littorinopsis) } \\
\text { planospira }\end{array}$ & 0.40 & 0.05 & 0.29 & 0.23 & 0.05 & 0.60 & 0.2 & 0.09 & 0.239 & 7 \\
\hline $\begin{array}{l}\text { Littorina } \\
\text { (Littorinopsis) } \\
\text { scabra }\end{array}$ & 0.25 & 0.25 & 0.33 & 0.23 & - & 0.35 & 0.15 & 0.05 & 0.230 & 8.5 \\
\hline Marcia & 0.25 & 0.05 & 0.09 & 0.18 & - & 0.05 & - & 0.14 & 0.127 & 17 \\
\hline Monodonta labio & - & 0.05 & 0.14 & 0.05 & - & 0.1 & - & 0.05 & 0.078 & 24 \\
\hline Morula fracella & 0.25 & 0.10 & 0.05 & 0.09 & 0.05 & 0.05 & - & - & 0.098 & 21 \\
\hline Nassarius & 0.05 & 0.15 & 0.05 & 0.09 & 0.10 & 0.10 & - & - & 0.173 & 11 \\
\hline Nerita olivaceous & 0.40 & 0.05 & 0.09 & 0.18 & 0.05 & 0.20 & 0.15 & - & 0.128 & 16 \\
\hline
\end{tabular}


Table 4. Continued

\begin{tabular}{|c|c|c|c|c|c|c|c|c|c|c|}
\hline \multirow{2}{*}{$\begin{array}{l}\text { Species of } \\
\text { Mollusk }\end{array}$} & \multicolumn{9}{|c|}{$\begin{array}{c}\text { Species Diversity (Margalef's index) of Mollusks in the Different } \\
\text { Mangrove Areas }\end{array}$} & \multirow[t]{2}{*}{ Rank } \\
\hline & $\mathrm{I}$ & II & III & IV & $\mathrm{V}$ & VI & VII & VIII & Mean & \\
\hline Nerita chamaeleon & 0.85 & 0.05 & 0.14 & 0.14 & 0.05 & 0.55 & 0.10 & 0.05 & 0.241 & 6 \\
\hline $\begin{array}{l}\text { Nerita } \\
\text { (Theleostyla) } \\
\text { squamulata }\end{array}$ & 0.40 & 0.1 & 0.09 & 0.18 & 0.24 & 0.65 & - & 0.09 & 0.250 & 5 \\
\hline Septifer bilocularis & 0.15 & 0.15 & 0.09 & 0.14 & 0.05 & 0.20 & - & 0.09 & 0.124 & 19 \\
\hline Tegillaria granosa & 0.35 & - & 0.09 & 0.09 & 0.14 & 0.35 & 0.10 & 0.05 & 0.167 & 13 \\
\hline $\begin{array}{l}\text { Telescopium } \\
\text { telescopium }\end{array}$ & 0.30 & 0.1 & 0.29 & 0.23 & 0.19 & 0.25 & 0.35 & 0.05 & 0.220 & 8.5 \\
\hline Terebralia sulcata & 0.90 & 0.45 & 0.33 & 0.68 & 0.29 & 0.75 & 0.75 & 0.50 & 0.593 & 1 \\
\hline
\end{tabular}

Note: The dash (-) sign indicates none (or 0) Species Diversity index.

Table 5 presents a summary of the species richness of mangrove-associated mollusks in all municipalities of Catanduanes island. The richness of mollusks found in mangrove areas of 3 municipalities, Pandan (1.69), Baras (1.27) and Bato (1.19) are higher than 1.0. The other 5 municipalities have lower richness values but almost approaching 1.0. The capital municipality of Virac (the most populous in the island in terms of human population) registered the lowest species richness index at 0.73 . Based on the factors affecting biodiversity as enumerated by Shanmugam and Vairamani (2009), the mollusks diversity in the island under study are observed to be affected by irrational or over-exploitation practices, human exploding population, human activity stress in the natural beds of mollusks, expansion of agricultural diversity and activities in the municipalities of Virac, Viga and Panganiban (showing lower species richness indices at $0.73,0.77$, and 0.74 , respectively). The effects of natural calamities on the biodiversity of mollusks in this island located in the "typhoon highway" of the Philippines appear to have greater significance. Sudden heavy downpour, typhoons, floods and tidal surges can lead to death of mollusks. The mollusks from rivers and estuaries of the island are carried by flood waters to the coastal waters and back during tidal surges. The present study observed empty shells which were also considered in the collections aside from the live specimens. It is highly likely that they are part of the mangrove areas surveyed. Although some shells may be transported for several kilometers, they still will be found within the extensive areas covered in this inquiry. 
Table 5. Species richness (Menhinick's index) of mollusks found in the mangrove areas in the different municipalities of Catanduanes.

\begin{tabular}{llcc}
\hline Municipality & Area & $\begin{array}{c}\text { Species Richness using Menhinicks's } \\
\text { Index }\end{array}$ & Ranking \\
\hline Bagamanoc & I & 0.81229 & 5 \\
Baras & II & 1.27565 & 2 \\
Bato & III & 1.19571 & 3 \\
Pandan & IV & 1.69940 & 1 \\
Panganiban & V & 0.74492 & 7 \\
San Andres & VI & 0.92861 & 4 \\
Viga & VII & 0.76692 & 6 \\
Virac & VIII & 0.72802 & 8 \\
& Sum & 8.15195 & \\
\hline
\end{tabular}

\section{Physical setting of the mangrove areas in Catanduanes}

Under the Physiographic Model, there are five terrigenous setting, namely, (1) River Dominated Allochthonous (RDA), (2) Tide Dominated Allochthonous, (3) Wave Dominated Barrier Lagoon (Autochthonous), (4) Composite River and Wave Dominated Setting, and (5) Drowned Bedrock Setting (Thom 1984). In addition, three carbonate settings are also considered in the discussion.

In the northeastern zone (Zone II) of the island, the presence of small rivers in Bagamanoc would indicate that mangrove areas have RDA setting. The mangrove stands at the mouth of Malaquio rivulet opens to the Tahidan point in this zone. Also on this zone, specifically the mangrove areas of Viga and Panganiban indicate that the dominant setting is characterized by RDA also. Using the topographic maps $(1: 1,000)$ from NAMRIA Philippines, and Google Earth generated maps indicate that the mangrove setting corresponds to RDA. There is a low tidal range as observed in the study area, evidenced by narrow tidal changes during the day, even during the neap tides.

Oco River discharge of freshwater and sediments leads to the rapid deposition of terrigenous silts and clay to form the huge deltas found in Viga reaching to Panganiban. This formation favored the rapid growth of Nypa fruticans during the natural regeneration and anthropogenic action by clearing the areas when gathering leaves for thatching of roofs. It could be claimed that deposition of allocthonous materials from the Oco River may have greatly influenced the mono-specific growth of Nypa. But the human intervention of planting more Nypa for economic purposes has invariably enhance towards monospecific growth of the Nypa in the area as also observed in the southeastern zone comprised of the municipalities of Bato, Baras and Gigmoto. Human interference by planting new fronds of Nypa have contributed much to the widespread growth of the palm in the said zones of the island. Relating this monospecificity of Nypa palm growth in the areas mentioned could have greater implications to biobelting or biowalling for the tsunamis (see Masagca \& Masagca 2009).

In the southern location (Zone IV), the Composite River and Wave-Dominated Setting is observed in Palnab-Pajo Area. Pajo River in the municipality of Virac, 
provides the freshwater supply and sediments of the said mangrove area. Based on the available topographic maps and actual ground data survey by morphometry, it appears that the setting of the mangrove area in Palnab-Pajo represents a combination of high wave energy and high river discharge. The sand that is de-bounced by Pajo river is redistributed by waves forming sand sheets, hence a coastal plane is formed.

In the southwestern location (Zone VI), it shows that the Agojo Mangrove ecosystem differs from the rest of the physical setting of the others. A Tide Dominated Allochthonous Setting (TDAS) occurs in this mangrove area. However, considering the absence of a major river that drains water and sediments, it shows that the carbonate setting is more observable. Agoho is an inlet and possible deposition dominated by the accumulation of carbonate due to wave or tide reworking is not remote.

In the northwestern location (Zone II), the mangroves of Caramoran are formed at the mouth of the rivulets near Tubli and Toytoy rivers. A composite river and wavedominated setting is observed similar to other municipalities. The mangrove stands found in Talisay and San Roque of the municipality of Bato have the Composite River and Wave Dominated Setting. The active channel is found in Batalay and shows to be fixed in position. Colonization of mangroves is widespread towards Talisay, San Roque and even as far as San Pedro. There are also slight mangrove formations at the mouth of the Bato River, where high tidal energy and bidirectional currents are observed near the Guinobatan areas with mangrove patches. Nypa formation is very dominant in the mangrove areas that contribute to the Nypa palm thatching industry or (tiklad industry) of the municipality. Along the eastern coast of Catanduanes, the presence of small rivers in the municipality of Baras provides the avenue for having the Wave-Dominated-Allochthonous setting.

\section{CONCLUSIONS}

Based on the results presented, it can be concluded that among the 57 species of molluscs identified, consisting of 27 gastropods and 30 bivalves, higher values in species diversity and richness of these mollusks are the prosobranch, Terebralia sulcata; corbiculid bivalve, Geloina coaxans; potamidiids, Cerithidea cingulata and Cerithidea rhizophorarum; and two other species of the genus Littorina (Littorinopsis).

\section{ACKNOWLEDGMENT}

The authors express their thanks to the administration of Pacific Island Institute for Pedagogy, Technology, Arts \& Sciences, Inc. (CEO Manrico T. Masagca) and the Catanduanes State Colleges (SUC President III Dr. Asuncion V. Asetre, VP for REPA Dr. Susan Santelices, CAS Dean Dr. Asuncion V. San Juan, CAS Associate Dean Dr. Igmedio Teves, and the CAS Natural Science Department Chair Dr. Teresita Avila). We thank the referees for the comments and suggestions to improve this paper. 


\section{REFERENCES}

Aksornkoae S. 1993. Ecology and management of mangroves. Gland, Switzerland,. IUCN, Wetlands and Water Resources Programme.

Brusca R.C. and G. J. Brusca. 1990. Invertebrates. Sinauer Associates, Sunderland, Mass, USA.

Cintron G. and Y.S. Novelli. 1984. Methods for studying mangrove structure, pp. 91-113. In: Snedaker \& Snedaker (eds.), Mangrove Ecosystem: Research Methods. UNESCO Paris.

Dartnall A.J. and M. Jones (eds.). 1986. A manual of survey methods: living resources in coastal areas. ASEANAustralia Cooperation Program on Marine Science handbook. Townsville: Australian Institute of Marine Sciences.

De la Cruz A.A. and J.F. Banaag. 1967. The ecology of a small mangrove patch in Matabungkay beach, Batangas province. Natural and Applied Science Bulletin, 20:486-494.

Hamilton L.S. and S.C. Snedaker (eds.). 1984. Handbook for mangrove area management. UNESCO and East West Center, Environment and Policy Institute, Hawaii.

Hendrickx M.E., Brusca R.C., Cordero C.M. and G. Ramírez. 2007. Marine and brackish-water molluscan biodiversity in the Gulf of California, Mexico, Scientia Marina, 71 (4): 637647.

Heywood V.H.1995. Global biodiversity assessment. UNEP, Cambridge University Press.

Macnae W. 1968. The flora and fauna of mangrove swamps of the Indo-Pacific Region. Advances in Marine Biology, 6:74-270.

Magurran A. 1988. Ecological diversity and its measurement. University of Cambridge Press, UK.

Maler K.G. 1997. Environment, poverty and economic growth. In: Annual World Bank Conference on Development Economics, B. Plaskovic \& J.E. Stiglitz (eds.), The World Bank.

Masagca J.T. 2006. Perceptiones de los maestros de ciencia y habitantes costeros sobre conservacion de la biodiversidad de manglar (Science teachers' and coastal dwellers' perceptions on mangrove biodiversity conservation). Revista de Educacion en Ciencias, Journal of Science Education, 7(1):24-29.

Masagca J.T. 2000. Diversity of the molluscan gastropods, Terebralia sulcata and Cerithidea cingulatum in two mangrove areas of Luzon Island. $22^{\text {nd }}$ Annual Scientific Meeting, National Academy of Science and Technology (NAST) held at Manila Hotel, Intramuros, Manila, July 5-6, 2000.

Masagca J.T. and M.T. Masagca. 2009. Distributional range of mangroves in Catanduanes Island, Philippines: Inputs to biobelting programs for tidal surges and tsunamis. Paper presented in the East Asian Seas Congress of PEMSEA, November 27-30, Philippine International Convention Center, Manila, Philippines.

McNeely J. A., Miller K.R., Reid W., Mittermeier R. and T. Werner.1990.Conservation of the world's biological diversity. Gland, Switzerland and Washington, IUCN. WRI, CI, WWF-US and WB.

Mendoza A.V. and E.T. Tribiana.1997. Brackishwater shells along the Eastern part of Catanduanes: An inventory. Poster presented in the 19th Annual Scientific Meeting of the NAST at Westin Plaza, Pasay City.

Morton J. 1990. The shore ecology of the tropical Pacific UNESCO ROSTSEA.

Reyes N.E. 1979.The molluscan fauna of mangrove Communities in Puerto Galera Mindoro, Oriental. MS Thesis, University of the Philippines, Quezon City.

Rios-Jara E. Ceciel-M. Navarro-Caravantes, Cristian-M. Galván-Villa and Ernesto Lopez-Uriarte. 2009. Bivalves and gastropods of the Gulf of Tehuantepec, Mexico: A checklist of species with notes on their habitat and local distribution. Journal of Marine Biology, an open access journal.

Sasekumar A. 1984. Methods for the study of mangrove fauna. In eds: S \& J Snedaker, Mangrove Ecosystem: Research Methods. Unesco Monographs on Oceanography Methodology. UNESCO, Paris. p. 145-161.

Shanmugam A. and S. Vairamani. 2009. Molluscs in Mangroves: A Case Study. In: International Training Course on Coastal Biodiversity in Mangrove Ecosystems: Unu-Inweh-Unesco International Training Course Manual, Kathiresan, K.K. and S.A. Khan (Eds.). Annamalai University (CAS in Marine Biology, Parangipettai), Annamalai Nagar, India, p. 446-457. 
Snedaker S.C. and J.G. Snedaker (eds.).1984.The mangrove ecosystem: research methods. UNESCO, Paris.

Soemodihardjo S. and I. Soerianegara. 1989. The status of mangrove forests in Indonesia, p. 73-114. In: Ishemat Soerianegara et al. (eds.), Proceedings of a Symposium on Mangrove Management: Its Ecological and Economic Considerations held in Bogor, Indonesia, August 9-11, 1988.BIOTROP Special Publication No. 37.

Thom B.G. 1984. Coastal geomorphology. In: Snedaker \& Snedaker (eds.), Mangrove Ecosystem: Research Methods. UNESCO Paris.

Tomlinson P.B. 1986. The botany of mangroves. Cambridge University Press: Cambridge.

UNESCO. 1979. The mangrove ecosystem: Uses and management implications. Report of a Unesco Regional Seminar held in Dacca, Bangladesh, Dec. Unesco Report in Marine Sciences No. 8.

Zamora P. 1989. Mangroves of the Philippines. BIOTROP Special Publication (Bogor, Indonesia), 37:43-65. 